\title{
The impact of gross domestic product on the financing and investment efficiency of China's commercial banks
}

\author{
Zhen Shi ${ }^{1}$, Shijiong Qin ${ }^{1}$, Yung-ho Chiu $^{2^{*}} \mathbb{D}$, Xiaoying $\operatorname{Tan}^{1}$ and Xiaoli Miao ${ }^{1}$
}

\author{
${ }^{*}$ Correspondence: \\ echiu@scu.edu.tw \\ ${ }^{2}$ Department of Economics, \\ Soochow University, Taipei \\ City, Taiwan \\ Full list of author information \\ is available at the end of the \\ article
}

\begin{abstract}
China's commercial banks have developed at a very rapid speed in recent decades. However, with global economic development slowing down, the impact of gross domestic product growth as an exogenous factor cannot be ignored. Most existing studies only consider the internal factors of banks, and neglect their external economic factors. This study thus adopts an undesirable dynamic slacks-based measure under an exogenous model in combination with the Kernel density curve to explore the efficiency of state-owned commercial banks (SOCBs), joint-stock commercial banks (JSCBs), and urban commercial banks (UCBs) in China from 2012 to 2018. The results show that SOCBs have the highest overall efficiency, followed by JSCBS, then UCBs. The efficiencies of SOCBs, JSCBs, and UCBs in the financing stage are greater than those in the investment stage, indicating that the latter stage brings down overall efficiency. Thus, all commercial banks need to focus on the efficiency of non-performing loans and return on capital. Finally, SOCBs need to strengthen internal controls, reduce non-performing loans and improve return on capital. JSCBs should actively expand its business while controlling costs, and UCBs should optimize its management.
\end{abstract}

Keywords: Commercial banks, GDP growth, UDSBM, Kernel density curve

\section{Introduction}

According to the latest data released by The People's Bank of China, the total assets of financial institutions reached 318.69 trillion Yuan at the end of 2019, with banking institutions accounting for $91 \%$. This shows that the banking industry plays an important role in promoting economic growth and prosperity by providing credit and financial services to other economic sectors. Gross domestic product (GDP) and other macroeconomic environments have a profound impact on the development of banks (see, e.g. Phan et al. 2019; Tang and Nguyen 2020). However, the external environment of China's banking industry has changed significantly in recent years under a slowing economy due to a drop in the annual GDP growth rate from $7.86 \%$ in 2012 to $6.11 \%$ in 2019 . In addition, industry development has been poor, as exemplified by the overall depression of the manufacturing industry, overcapacity of traditional industries, and decline of profitability. The pressure these external environments have

(c) The Author(s) 2021. This article is licensed under a Creative Commons Attribution 4.0 International License, which permits use, sharing, adaptation, distribution and reproduction in any medium or format, as long as you give appropriate credit to the original author(s) and the source, provide a link to the Creative Commons licence, and indicate if changes were made. The images or other third party material in this article are included in the article's Creative Commons licence, unless indicated otherwise in a credit line to the material. If material is not included in the article's Creative Commons licence and your intended use is not permitted by statutory regulation or exceeds the permitted use, you will need to obtain permission directly from the copyright holder. To view a copy of this licence, visit http://creativecommons. org/licenses/by/4.0/. 
put on China's commercial banks necessitate an analysis of the efficiency of commercial banks in a macroeconomic context of GDP growth. Research into this topic could promote the healthy and rapid advancement of the financing and investment businesses of commercial banks and help them better adapt to the complex external environment, while also supporting the stable development of the national economy.

Many local and international scholars have presented outstanding contributions to the literature on commercial banks. Zhang et al. (2020a, b) examined banking institutions in 90 counties of 14 Chinese provinces between 2005 and 2013. They found that large state-owned commercial banks (SOCBs) are more responsive to political pressure, while joint-stock commercial banks (JSCBs) and urban commercial banks (UCBs) are more profit-oriented. Zhu et al. (2020a, b) ranked the performance of 16 major commercial banks in China according to their average marginal impact on structural efficiency. Their research results further confirmed that large commercial banks have a better operating performance than small- and medium-sized ones.

In the basic data envelopment analysis (DEA) model, the average banking efficiency of all countries is exceptionally low because current studies do not fully consider the significant impact of a country's macro-level environment on banks. However, when comparing the efficiency of banks in different countries or regions, it is essential to include environmental variables for adjustment. Considering the different environmental conditions would significantly improve the average efficiency value of almost all countries (see, e.g., Lozano-Vivas et al. 2002; Shyu et al. 2015; Shi et al. 2020). Based on this, the contributions of our paper are as follows. First, we incorporate environmental variables into the model and take GDP growth as an exogenous variable to more accurately reflect the efficiency of China's commercial banks. Second, the research is divided into two stages of financing and investment. We compare SOCBs, JSCBs, and UCBs in greater detail to provide data support for the analysis of China's banking industry.

The rest of the paper is organized as follows. Section 2 reviews the existing literature. Section 3 introduces the methods and models used herein. Section 4 presents an empirical analysis that proves the scientific nature of GDP growth as an exogenous variable. This is done by comparing the two scenarios with and without exogenous variables. At the same time, the paper suggests three forms of banks in Sect. 5, through the analyses of the financing and investment efficiency of SOCBs, JSCBs, and UCBs, and those of each input-output variable, providing a scientific basis for their healthy development.

\section{Literature review}

The literature review of this article is divided into two parts: social economy and commercial banks, and the management of commercial banks. The factors that influence the development of commercial banks can be divided into internal and external factors. Internal factors mainly include non-performing loans, deposits, board independence, scale, and so on, while external factors typically cover social and economic development, market structure adjustment, and Internet finance, among others. In terms of management, commercial banks typically strive to improve service quality and optimize the layout of bank outlets to promote development. 


\section{Social economy and commercial banks}

Social economic development, financial market structure, and other macroeconomic factors have a profound impact on the development of commercial banks. Unvan and Yakubu (2020) found that profitability, bank size, and liquidity are all important determinants of bank deposits when controlled by macroeconomic factors. Macroeconomic instability due to inflation also has a significantly negative impact on bank deposits. Tan et al. (2016) learned that taxes, overhead costs, labor productivity, and inflation were factors that affected the profitability of SOCBs, JSCBs, and UCBs in China. Among all types of commercial banks, China's JSCBs and UCBs have a lower return on assets, net interest margin, and profit margin compared with SOCBs. Zhao et al. (2020) studied the efficiency of 65 UCBs in 26 regions of China from 2013 to 2017 and found a significant spatial dependence between the loans of UCBs in China and those of banks in neighboring region. In the development process of UCBs in China, the adjustment of market structure promotes the improvement of bank efficiency.

Chen et al. (2020) took 171 Chinese commercial banks from 2004 to 2012 as the research objects and used the global-SMB model to estimate their total factor efficiency (TFE), and the TFE of each factor of production by internalizing a bank's overall risk as an undesirable by-product in the bank's production process. The results showed that shadow banking, bank size, non-performing loan ratio, loan-to-deposit ratio, fiscal surplus to GDP ratio, and banking concentration ratio are important determinants of bank efficiency. Zhu et al. (2019) specifically studied the impact of shadow banking. Taking Chinese commercial banks from 2003 to 2017 as samples, Fang et al. (2019) found that bank size, cost efficiency, profit efficiency, and inflation significantly correlate with bank profitability. In addition, their study noted that cost efficiency has a stronger positive impact on profitability when banks are exposed to higher levels of risk and more competition. Based on the DEA SBM-undesirable model and window analysis, Guo et al. (2020) pointed out that SOCBs were more efficient than JSCBs before 2012. After 2012, the opposite was true. In addition, net interest margin, non-interest income ratio, gross fixed asset investment growth rate, and consumer price index have significantly positive effects on bank efficiency, while the cost-benefit ratio has a significantly negative impact on bank efficiency. In addition, their study also presented the threshold effect of the ratio of non-interest income on bank efficiency. Afza and Asghar (2017) concluded that commercial banks operate at optimal levels because of their large size, increased solvency, and greater minimum capital requirements.

The internal governance system of commercial banks also affects banking efficiency. Based on the data analysis of many commercial banks, some scholars (see, e.g., Rehman et al. 2020; Karkowska and Acedanski 2020) found that board independence has a negative impact on banking efficiency. Meanwhile, Rehman et al. (2020) found that it has a positive impact on banking efficiency after the bank goes public. Using non-oriented, variable return-to-scale dynamic network SBM, Kweh et al. (2018) noted that the number of directors on the risk management committee has a positive effect on bank performance. At the same time, an increase in the number of independent directors improves a firm's profit efficiency, but reduces its operating efficiency.

With the development of network technology, the influence of Internet finance on the efficiency of commercial banks cannot be underestimated. Xu and Zhou (2020) used a 
two-stage assurance region DEA model (AR-DEA) to analyze the efficiency of 26 listed commercial banks in China, divided into SOCBs, JSCBs, and UCBs, from 2013 to 2017. The results showed that SOCBs performed the best among the three. Moreover, they discovered that the development of Internet finance has a positive impact on the deposit producing sub-stage. Xu et al. (2020) established a credit risk measurement system suitable for commercial banks, pointing out that the development of network finance has brought different influences to a bank's business, business model, and business philosophy. Based on the current banking systemic risk measured by the Systemic Contingent Claims Analysis (SCCA) model and a stepwise regression, Zhu and Hua (2020) examined the impact of Internet finance on China's banking sector and speculated that risks could rise in the future. Based on data from 200 commercial banks in China from 2011 to 2016, Chen et al. (2019) concluded that peer-to-peer (P2P) lending and third-party payments have a significantly negative impact on the profitability of deposits and loans. The development of Internet finance has reduced the interest income of loans, increased the interest cost of deposits, and cut the growth rate of loans and deposits. In sum, the development of the Internet has brought forth more risks. Compared with large stateowned and joint-stock banks, urban, rural, and unlisted banks are more vulnerable to the impact of Internet finance.

\section{Management of commercial banks}

Different scholars have conducted extensive research on the management and operational efficiency of commercial banks through various perspectives and methods. Mester (1997) suggested the importance of studying banks' X-inefficiency to account for differences across the markets in which they are operating. Furthermore, because $\mathrm{X}$-inefficiency is, by construction, a residual, it will be particularly sensitive to omissions in the basic model. Allen et al. (2006) compared the efficiency of Canada's largest banks with U.S. commercial banks by key performance ratios, economies of scale, and costinefficiency. Based on the U.S. Federal Deposit Insurance Corporation (FDIC) data from 2001 to 2016, Calmès and Théoret (2020) found that non-interest income continues to make a positive contribution to U.S. banks' results. In addition, trading, loan sales, and securitization increase the flexibility of banks' risk management. Based on the payment and transaction data provided by banks, Kou et al. (2021) established the bankruptcy prediction model.

The China Banking Regulatory Commission in 2013 implemented the Measures for the Administration of Inter-bank Lending by commercial banks. By collecting data from 231 commercial banks in China, Zhang et al. (2018) found that macroprudential policies (MPPs) can be used by regulators to manage bank risk-taking and reduce the vulnerability of the banking sector, which is beneficial for the sustainable development of the banking system and overall financial stability. Wang et al. (2020) modeled credit rating in P2P lending as a cost-sensitive multi-class classification problem to reduce total cost.

Financial system risk is an important issue in the banking industry. Ji et al. (2019) reported that the transformation of the financial system to a more market-oriented structure could reduce banks' systemic risk. Kou et al. (2019) introduced the current situation of using machine learning methods to study financial system risk, and put forward the direction of future work. Kou et al. (2014) presented a multiple criteria 
decision making (MCDM)-based approach to sort and select popular clustering algorithms in financial risk analysis.

Zhang et al. (2020a, b) studied data from 30 commercial banks (13 large banks, 17 small banks) and 56 non-bank financial institutions from 2006 to 2016. They used the Z-score as a measure of risk, where the higher its value, the lower the risk for bankruptcy. The authors offered commercial banks a way to find the best merger partners. Shen and Cai (2020) pointed out how commercial banks choose the most appropriate and effective channel of investment according to national and economic conditions. Tang et al. (2020) emphasized the importance of the service quality of commercial banks to their development. Ausloos et al. (2019) proposed that after China's interest rate liberalization, all commercial banks should adopt appropriate measurement methods according to their own conditions and set up interest rate risk management departments. To follow the trend of decreasing the number of offline customers caused by Internet development, Xue et al. (2019) suggested that commercial banks adjust and optimize their physical branch layout. This not only reduces the operating costs of banks and prevents them from wasting resources, but it can also be make their operations more sustainable.

Sun et al. (2017) argued that banks should monitor rapidly changing customer needs. Banks could work with information technology (IT) companies to offer products that are more customer-centric. Bank managers must proactively adapt to their environment and strike the right balance between regulation and innovation. Liu et al. (2020) conducted an empirical analysis on the operating data of 71 commercial banks in China spanning the period 2011 to 2015. Using the two-stage meta-front DEA network model and multiple regression model, the main empirical results showed that state-owned banks had the highest technical and management level regardless of the efficiency of deposits and loans. In contrast, UCBs should improve their technical and management level and strive to narrow the gap with joint-stock banks. According to the two-stage inverse DEA with undesirable outputs, An et al. (2019) suggested that China's commercial banks should do the following: (1) increase their operating costs and interest expenses to fulfill their short-term tasks; (2) keep the amount of deposits at a reasonable and effective level; (3) improve the business level of their employees; and (4) scrutinize the creditworthiness of their borrowers. Large-scale group decision-making (LSGDM) problems in the banking industry also need to be improved. Chao et al. (2021) built a consensus reaching model for a heterogeneous LSGDM that addressed non-cooperative behaviors, and discussed its application in inclusive finance. The results showed that the proposed consensus model can integrate the opinions of participants with different preference formats and reach consensus effectively.

In conclusion, we know that banking efficiency is influenced by internal and external factors. While bank management can only optimize internal factors, the change in the total efficiency of different economic environments cannot be ignored. Hence, this paper fully considers internal and external factors, and uses undesirable dynamic slacks-based measures (UDSBM) under an exogenous model to study the overall efficiency, stage efficiency, and improvement of SOCBs, JSCBs, and UCBs in greater detail. The existing literature has been of great help to this study, and some key studies are listed below in Table 1. 
Table 1 Key literature

\begin{tabular}{|c|c|c|c|}
\hline Author(s) & Object & Key variable(s) & Method(s) \\
\hline Mester (1997) & U.S. banks (1991-1992) & X-Inefficiency & $\begin{array}{l}\text { Stochastic econometric cost } \\
\text { frontier methodology }\end{array}$ \\
\hline Allen et al. (2006) & $\begin{array}{l}\text { Canada-U.S. banks } \\
(1983-2004)\end{array}$ & $\begin{array}{l}\text { Performance ratios; } \\
\text { Economies of scale; } \\
\text { Cost-Inefficiency }\end{array}$ & Translog cost function \\
\hline Calmès and Théoret (2020) & $\begin{array}{l}\text { U.S. Federal Deposit } \\
\text { Insurance Corporation } \\
(2001-2016)\end{array}$ & $\begin{array}{l}\text { Non-interest income; } \\
\text { Banks'risk-adjusted ROA }\end{array}$ & OLS and GARCH \\
\hline Afza and Asghar (2017) & $\begin{array}{l}\text { Commercial banks in } \\
\text { Pakistan (2005-2010) }\end{array}$ & $\begin{array}{l}\text { Profit Efficiency; } \\
\text { Cost Efficiency }\end{array}$ & $\begin{array}{l}\text { Stochastic Frontier Approach } \\
\text { (SFA) and value-added } \\
\text { approach }\end{array}$ \\
\hline Kweh et al. (2018) & $\begin{array}{l}\text { Islamic and conventional } \\
\text { banks (2008-2017) }\end{array}$ & $\begin{array}{l}\text { Profitability Efficiency; } \\
\text { Managerial Efficiency }\end{array}$ & $\begin{array}{l}\text { Non-oriented, variable } \\
\text { returns-to-scale dynamic } \\
\text { network SBM model }\end{array}$ \\
\hline Liu et al. (2020) & $\begin{array}{l}71 \text { commercial banks in } \\
\text { China (2011-2015) }\end{array}$ & $\begin{array}{l}\text { Deposits Efficiency; } \\
\text { Loans Efficiency }\end{array}$ & $\begin{array}{l}\text { Meta-frontier DEA network } \\
\text { model }\end{array}$ \\
\hline This study & $\begin{array}{l}33 \text { commercial banks in } \\
\text { China (2012-2018) }\end{array}$ & $\begin{array}{l}\text { GDP growth; } \\
\text { Financing Efficiency; } \\
\text { Investment Efficiency }\end{array}$ & $\begin{array}{l}\text { Undesirable dynamic SBM } \\
\text { under exogenous model }\end{array}$ \\
\hline
\end{tabular}

\section{Research method}

Farrell (1957) measured productivity by connecting the most efficient production point to the production boundary. The difference between any real production point and the production boundary indicates the inefficiency of the production point. Based on this, Charnes et al. (1978) extended his theory to establish a generalized mathematical linear programming model, called CCR (Charnes, Cooper \& Rhodes, 1978). Banker et al. (1984) then proposed the BCC model (abbreviation for Banker R.D.; Charnes A.; Cooper W.W.) and revised the fixed scale return originally assumed in the CCR model into the variable scale return. Tone (2011) proposed the difference variable model (SBM), that is, the difference variable is used as the measurement basis, and the difference between input and output is considered.

In order to analyze efficiency in greater depth, many scholars divided the entire business process into several sub-processes, connected each stage with some intermediate outputs, and calculated the efficiency of each stage under different conditions. Tone and Tsutsui (2009) put forward the weighted SBM network DEA model and used the SBM model to obtain the optimal solution based on the network DEA model built on the connections between various departments of the decision-making unit (DMU). Traditional DEA cannot analyze the efficiency of individual departments, but network DEA can resolve this problem. A company's operations generally span many periods, and the dynamic DEA model can be used for such analysis. If departments and time need to be simultaneously evaluated, then both network and dynamic DEA should be combined. However, the Tone and Tsutsui dynamic network DEA model does not consider output, and exogenous variables affect any unfavorable situation. In addition, banks have different sizes, management models, and so on, but the efficiency evaluation using traditional DEA generally assumes all DMUs have the same technical level. The traditional efficiency evaluation model may be less appropriate. Hence, this paper combines the concepts of the Tone and Tsutsui and SBM model, non-desirable outputs, exogenous variables, and the common boundary model of Donnell 
(2008) to set up a new model, called the meta UDSBM under an exogenous model. This model is used to evaluate the financing and investment efficiency of 34 listed commercial banks in China during 2012-2018.

Suppose there are n DMUs $(j=1 \ldots, n)$, each of which has $K$ sections $(k=1 \ldots K)$ and $T$ time periods $(t=1 \ldots, T)$. Each DMU has an input and output for time period $\mathrm{t}$ and a connection to the next time period. We use $X_{k}$ and $Y_{k}$ to represent the input and output of each $K$ branch, $(k, h)_{i}$ denoting the branch from $K$ to $H$. Let output $Y$ be divided into $\left(Y_{\text {good }} Y_{\text {bad }}\right)$, where $Y_{\text {good }}$ is a desirable output, $Y_{\text {bad }}$ is an undesirable output, and $Z_{\text {input }}$ is a carry-over link from period $t$ to period $t+1$. $E_{a j t}(a=1 \ldots u)$ is an exogenous variable outside of a given economic model that often impacts the outcome of the model. The following is the non-oriented model:

(1) Financing Stage: The input indicator is the number of employees and operating expenses, represented by $X_{1}^{t}$; the output indicator is inter-bank borrowing and deposits, represented by $Y_{1 \text { good }}^{t}$

(2) Investment Stage: The output variables are divided into desirable output and undesirable output. Desirable output is $Y_{2 g o o d}^{t}$, which is the return on capital; undesirable output is $Y_{2 b a d}^{t}$, which is the non-performing loans;

The exogenous variable is $E_{o k}^{t}$, which means GDP growth; and the carry-over variable

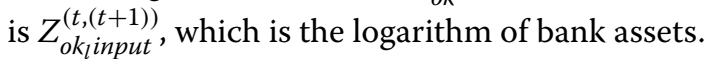

Meta undesirable dynamic slacks-based measures (SBM) under an exogenous model

Meta-frontier (MF)

(a) Objective function:

Overall efficiency:

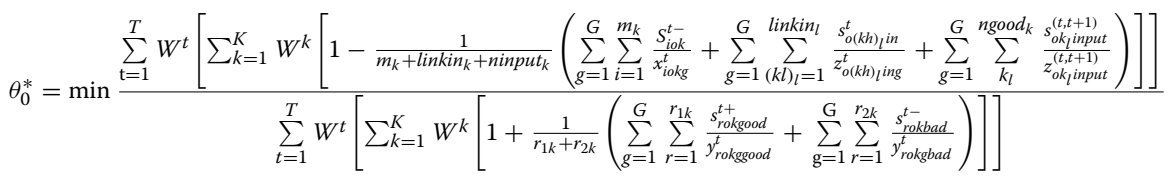

Stage efficiency:

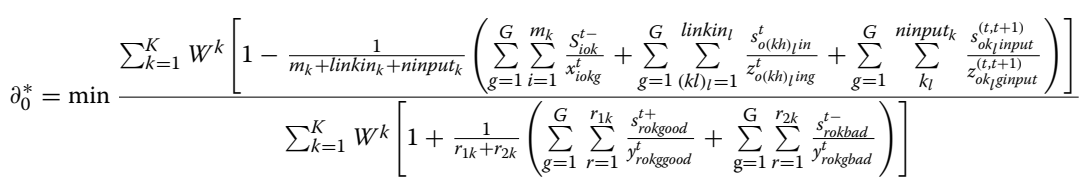

Subject to:

Financing Stage:

$$
\begin{aligned}
& x_{o 1}^{t}=X_{1}^{t} \lambda_{1}^{t}+s_{1 o}^{t-}(\forall t) \\
& y_{o 1 \text { good }}^{t}=Y_{1 \text { good }}^{t} \lambda_{1}^{t}-s_{1 \text { ogood }}^{t+}(\forall k, \forall t, \forall g) \\
& \lambda_{1}^{t} \geq 0, s_{1 o}^{t-} \geq 0, s_{1 \text { ogood }}^{t+} \geq 0 \\
& Z_{o(12) \text { in }}^{t}=Z_{(12) \text { in }}^{t} \lambda_{1}^{t}+S_{o(12) \text { in }}^{t}((1,2) i n)
\end{aligned}
$$


Investment Stage:

$$
\begin{aligned}
& y_{\text {o2good }}^{t}=Y_{2 \text { good }}^{t} \lambda_{2}^{t}-s_{2 o g o o d}^{t+}(\forall k, \forall t, \forall g) \\
& y_{o 2 b a d}^{t}=Y_{2 b a d}^{t} \lambda_{2}^{t}+s_{2 o b a d}^{t-}(\forall k, \forall t, \forall g) \\
& \lambda_{2}^{t} \geq 0, s_{2 o}^{t-} \geq 0, s_{2 o g o o d}^{t+} \geq 0, s_{2 o b a d}^{t+} \geq 0 \\
& E_{\mathrm{ok}}^{\mathrm{t}}=E_{\mathrm{kg}}^{\mathrm{t}} \lambda_{\mathrm{kg}}^{\mathrm{t}}(\forall k, \forall t, \forall g)
\end{aligned}
$$

(b1) Period efficiency:

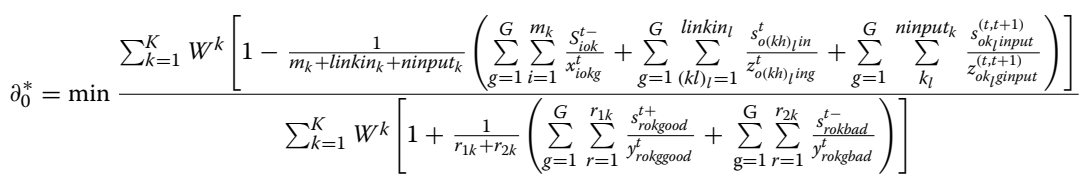

\section{(b2) Division efficiency:}

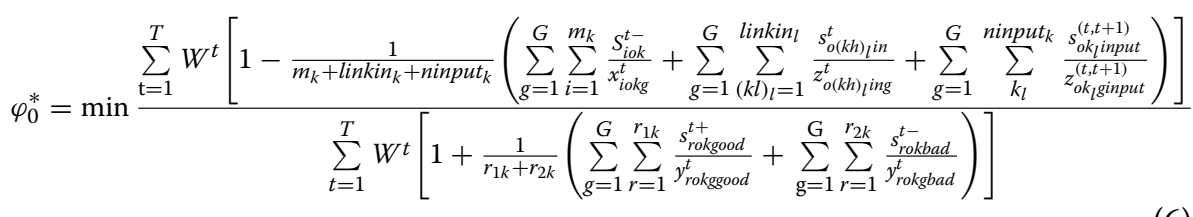

(b3) Division period efficiency:

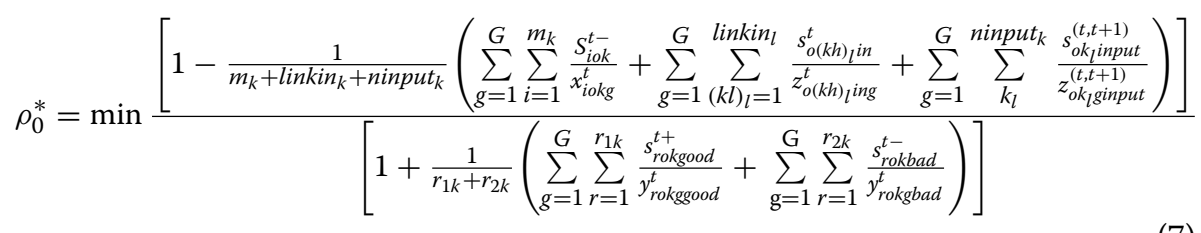

From the above, we can obtain overall efficiency, period efficiency, division efficiency, and division period efficiency using the meta-frontier model.

\section{Group-frontier (GF)}

As each DMU under the group frontier chooses the most favorable final weighted output, the DMU efficiencies under the group frontier are solved using the following equations:

\section{(a) Objective function:}

Overall efficiency:

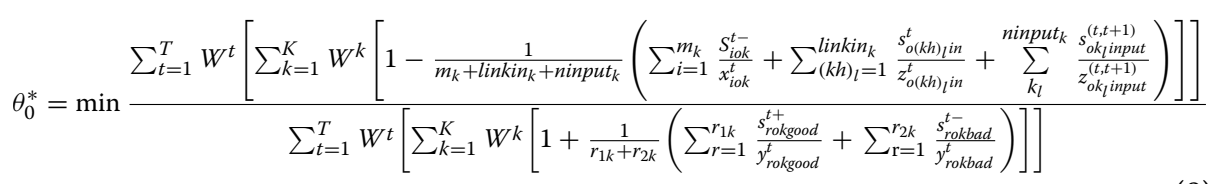

Subject to:

Financing Stage: 


$$
\begin{aligned}
& x_{o 1}^{t}=X_{1}^{t} \lambda_{1}^{t}+s_{1 o}^{t-}(\forall t) \\
& y_{\text {o1good }}^{t}=Y_{1 \text { good }}^{t} \lambda_{1}^{t}-s_{1 \text { ogood }}^{t+}(\forall k, \forall t, \forall g) \\
& \lambda_{1}^{t} \geq 0, s_{1 o}^{t-} \geq 0, s_{1 o g o o d}^{t+} \geq 0,(\forall k, \forall t, \forall g) \\
& Z_{o(12) \text { in }}^{t}=Z_{(12) \text { in }}^{t} \lambda_{1}^{t}+S_{o(12) \text { in }}^{t}((1,2) \text { in })
\end{aligned}
$$

Investment Stage:

$$
\begin{aligned}
& y_{\text {oggood }}^{t}=Y_{2 g o o d}^{t} \lambda_{2}^{t}-s_{2 o g o o d}^{t+}(\forall k, \forall t, \forall g) \\
& y_{o 2 b a d}^{t}=Y_{2 b a d}^{t} \lambda_{2}^{t}+s_{2 o b a d}^{t-}(\forall k, \forall t, \forall g) \\
& \lambda_{2}^{t} \geq 0, s_{2 o}^{t-} \geq 0, s_{2 o g o o d}^{t+} \geq 0, s_{2 o b a d}^{t+} \geq 0, \quad(\forall k, \forall t, \forall g) \\
& E_{\mathrm{ok}}^{\mathrm{t}}=E_{\mathrm{kg}}^{\mathrm{t}} \lambda_{\mathrm{kg}}^{t}(\forall k, \forall t, \forall g)
\end{aligned}
$$

\section{(b) Period and division efficiencies}

The period and division efficiencies are as follows.

(b1) Period efficiency:

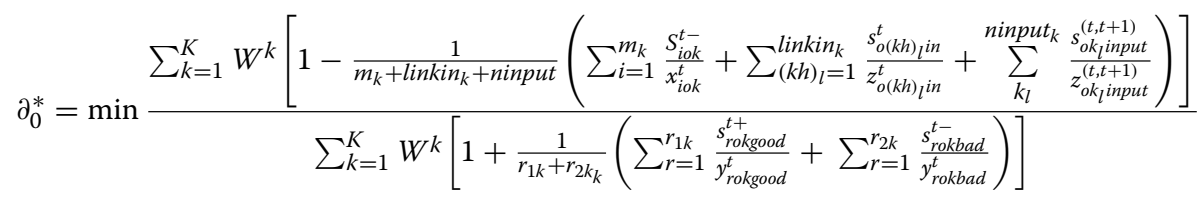

(b2) Division efficiency:

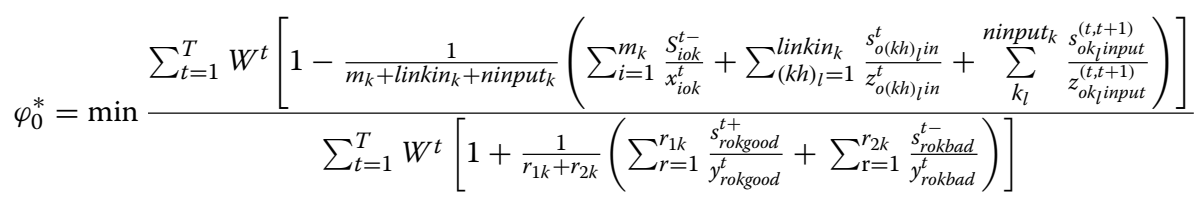

(b3) Division period efficiency:

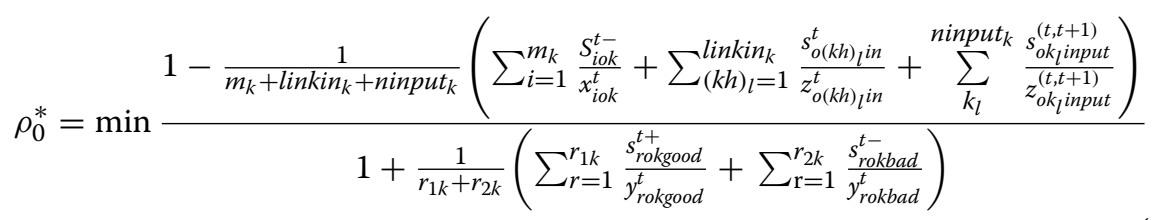

From the above formulae, we obtain overall efficiency, period efficiency, division efficiency, and division period efficiency. The efficiencies of input and outputs (Desirable and Undesirable) are defined in the following formulae (14-16):

$$
\text { Input efficiency }=\frac{\text { Actual input }}{\text { Target input }}
$$

Desirable output efficiency $=\frac{\text { Target Undesirable output }}{\text { Actual Undesirable output }}$ 
Table 2 Classification of 34 Chinese Commercial Banks

\begin{tabular}{ll}
\hline Cluster & DMU \\
\hline SOCBs & Bank of China (BOC), China Construction Bank (CCB), Industrial and Commercial Bank of China (ICBC), \\
& Agricultural Bank of China (ABC), Bank of Communication (BCM), Postal Savings Bank of China (PSBC) \\
JSCBs & China Industrial Bank (CIB), Ping An Bank (PAB), Shanghai Pudong Development Bank (SPDB), China \\
& Minsheng Banking Co., Ltd. (CMBC), China Merchants Bank (CMB), China Citic Bank (CNCB), China \\
& Everbright Bank (CEB), Hua Xia Bank (HXB), China Zheshang Bank (CZB) \\
UCBs & Bank of Beijing (BOB), Bank of Shanghai (BOS), Bank of Nanjing (BONJ), Bank of Chengdu (BOCD), Bank \\
& of Ningbo (BONO), Bank of Shengjing (BOSJ), Bank of Hangzhou (BOHZ), Bank of Guiyang (BOGY), \\
& Bank of Zhengzhou (BOZZ), Bank of Jiangsu (BOJS), Bank of Changsha (BOCS), Bank of Chongqing \\
& (BOCQ), Bank of Qingdao (BOQD), Bank of Huishang (BOHS), Bank of Harbin (BHRB), Bank of Gansu \\
& (BOGS), Bank of Jiangxi (BOJX), Bank of Jiujiang (BOJJ), Bank Of Xi'An (BOXA)
\end{tabular}

Table 3 Input and output variables

\begin{tabular}{llll}
\hline Stage & Variable & & Unit \\
\hline Financing stage & Input & Operating expenses & $10^{7} \mathrm{RMB}$ \\
& & Number of employees & People \\
& Output & Deposits & $10^{7} \mathrm{RMB}$ \\
& & Inter-bank borrowing & $10^{7} \mathrm{RMB}$ \\
Carry-over & Logarithm of bank assets & \\
Investment stage & Output & Return on capital & $\%$ \\
& & Non-performing loans & $10^{7} \mathrm{RMB}$ \\
Exogenous variable & GDP growth & $\%$ \\
\hline
\end{tabular}

$$
\text { Undesirable output efficiency }=\frac{\text { Actual Undesirable output }}{\text { Target Undesirable output }}
$$

\section{Kernel density analysis}

As a non-parametric estimation method, kernel density estimation is mainly used to obtain the distribution pattern of random variables by smoothing their probability density based on the kernel function, which is widely used in the analysis of regional differences. Here, $X_{1}, X_{2} \ldots, X_{n}$ make up the sample of a unary continuous population, and formula (17), given by Kristan and Leonardis (2014), is the kernel density estimation of the density function $f(x)$ at any point $x$. Here, $f(x)$ is defined as the density function, $K(\cdot)$ is the kernel density function, and $\mathrm{h}$ is the bandwidth.

$$
f_{h}(x)=\frac{1}{n h} \sum_{i=1}^{n} K\left(\frac{x-X_{i}}{h}\right)
$$

This paper selects the commonly-used Gaussian kernel function (EI Heda and Louani 2018) to estimate the kernel density curve of the distribution pattern of commercial banks' efficiency under China's GDP growth rate. See formula (18). Based on the sample data, the efficiency values of 34 commercial banks in China under the influence of GDP are described. 


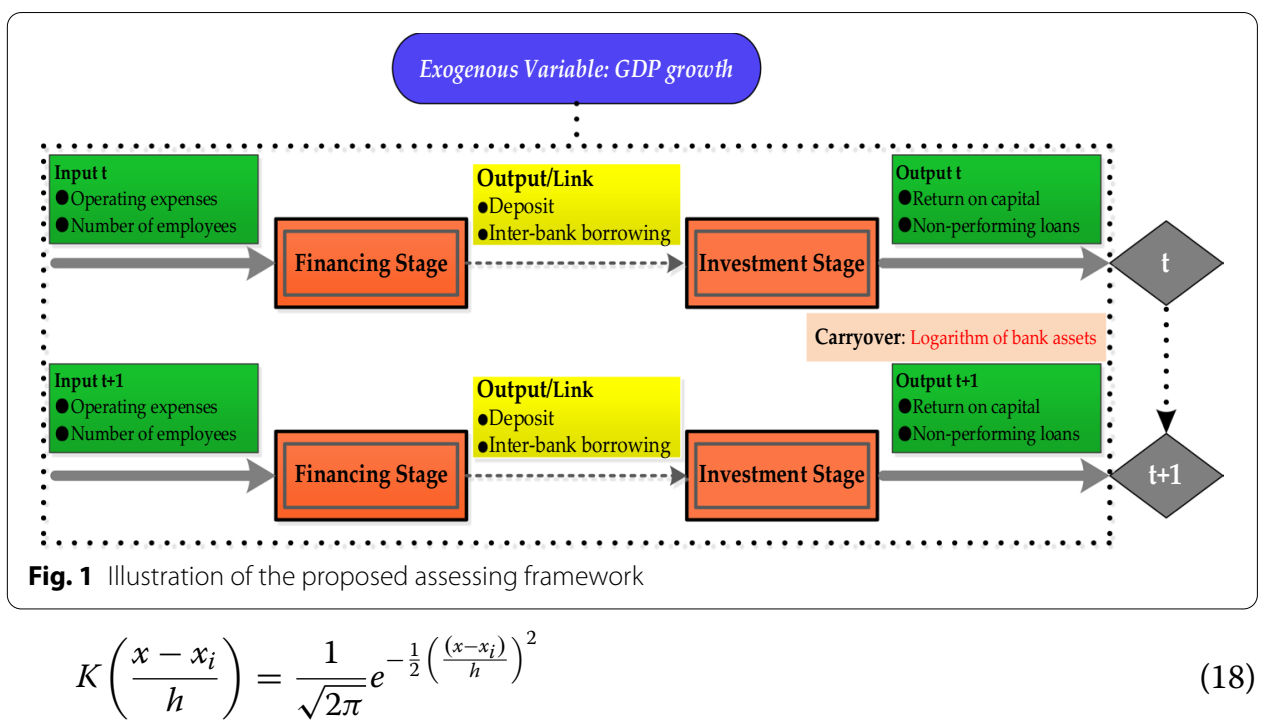

\section{Empirical analysis}

\section{Data description}

\section{Variables}

This paper takes 34 Chinese commercial banks as the research object. According to the nature of commercial banks, they can be divided into three categories: SOCBs, JSCBs, and UCBs. Table 2 lists the specific banks included under the three types of commercial banks.

Using UDSBM under an exogenous model, the research is divided into two stages: financing and investment. In the financing stage, the operating expenses and number of employees are input variables. Deposits and inter-bank borrowing are both acceptable output indicators. In the investment stage, the output variables are return on capital and inter-bank borrowing, among which the latter is the non-desirable output index, and the former is the desirable output index. This study also selects the logarithm of bank assets as the carryover variable, and GDP growth as the exogenous variable. See Table 3 for details.

The specific variables are explained as follows.

(1) Operating expenses. The expenses incurred in the business operations and management of a commercial bank.

(2) Number of employees. The total number of employees in commercial banks.

(3) Deposits. The total amount of deposits attracted by commercial banks, mainly from funds attracted by trading and non-trading accounts. Deposits are the main source of funds for commercial banks.

(4) Inter-bank borrowing. The mutual adjustment between banks in order to solve the shortage of funds in the short term.

(5) Logarithm of bank assets. We choose fixed asset investment to present bank assets. Fixed asset investment refers to the amount of work undertaken by a commercial bank to construct and acquire fixed assets over a period of time, and the variation in costs associated with them, expressed in monetary terms. 
Table 4 Statistical Description of inputs and outputs

\begin{tabular}{|c|c|c|c|c|c|c|c|c|}
\hline \multirow[t]{3}{*}{ Item } & \multirow{3}{*}{$\begin{array}{l}\text { Exogenous } \\
\text { variable } \\
\text { GDP growth } \\
(\%)\end{array}$} & \multicolumn{4}{|c|}{ Financing Stage } & \multicolumn{3}{|c|}{ Investment Stage } \\
\hline & & \multicolumn{2}{|l|}{ Input } & \multicolumn{2}{|l|}{ Output } & \multirow{2}{*}{$\begin{array}{l}\text { Carry-over } \\
\text { Logarithm } \\
\text { of bank } \\
\text { assets }\end{array}$} & \multicolumn{2}{|l|}{ Output } \\
\hline & & $\begin{array}{l}\text { Operating } \\
\text { expenses } \\
\left(10^{7} \mathrm{RMB}\right)\end{array}$ & $\begin{array}{l}\text { Number of } \\
\text { employees } \\
\text { (People) }\end{array}$ & $\begin{array}{l}\text { Deposits } \\
\left(10^{7} \mathrm{RMB}\right)\end{array}$ & $\begin{array}{l}\text { Inter-bank } \\
\text { borrowing } \\
\left(10^{7} \mathrm{RMB}\right)\end{array}$ & & $\begin{array}{l}\text { Non- } \\
\text { performing } \\
\text { loans } \\
\left(10^{7} \mathrm{RMB}\right)\end{array}$ & $\begin{array}{l}\text { Return on } \\
\text { capital } \\
(\%)\end{array}$ \\
\hline Max & 7.90 & $19,214.97$ & $198,182.67$ & $907,416.87$ & $165,730.00$ & 4.4 & $14,177.37$ & 4.01 \\
\hline Min & 6.70 & 2528.58 & $31,705.33$ & $134,239.47$ & $29,435.47$ & 1.35 & 165.81 & 3.19 \\
\hline Mean & 7.21 & 9516.77 & $121,049.67$ & $448,654.76$ & $76,623.03$ & 2.8194 & 4840.70 & 3.73 \\
\hline SD & 0.49 & 4455.35 & $53,865.67$ & $193,635.43$ & $35,172.45$ & 0.74796 & 3662.89 & 0.29 \\
\hline
\end{tabular}

(6) Return on capital. The net income figure provided in the income statement for a settlement period, divided by the quotient of the total investment-namely, the ratio of net income to the total investment.

(7) Non-performing loans. This is a general term for delinquent loans, sluggish loans, and bad loans. Overdue loans refer to those that fail to be repaid upon the expiration of the loan contract (including the expiration after any extension). Sluggish loans are those that are overdue (including the expiration after any extension), but have not been repaid beyond the prescribed period of time, or loans whose production and operation have been terminated and the project stopped while the period of time has not yet expired. Bad loans are loans classified as bad in accordance with relevant regulations.

(8) GDP growth. The GDP index is the relative number reflecting the trend and degree of GDP change within a certain period. The index is calculated on the basis of the previous year and at constant prices.

Figure 1 illustrates the structure of this paper.

\section{Statistical description}

This section studies GDP growth, operating expenses, number of employees, deposits, inter-bank borrowing, non-performing loans, return on capital, and the logarithm of bank assets, of SOCBs, JSCBs, and UCBs from 2012 to 2018. The maximum, minimum, mean, and standard deviation of the eight variables are calculated respectively, and the results are kept at two decimal places. In general, UCBs have the lowest value for the four variables. See Table 4 for details.

\section{Scenario analysis of the efficiency}

\section{GDP growth and bank earnings}

Gross domestic product growth and banking efficiency interact. Calmes and Theoret (2020) noted that effective liquidity matching requires banks to track external shocks, such as GDP growth shocks, in order to optimize the allocation of assets between loans and other lines of business. At the same time, changes in banks may in turn affect economic and financial conditions such as GDP. Taking 108 real estate banks from the U.S., the U.K., and Germany from 2000 to 2014 as samples, Martins et al. 


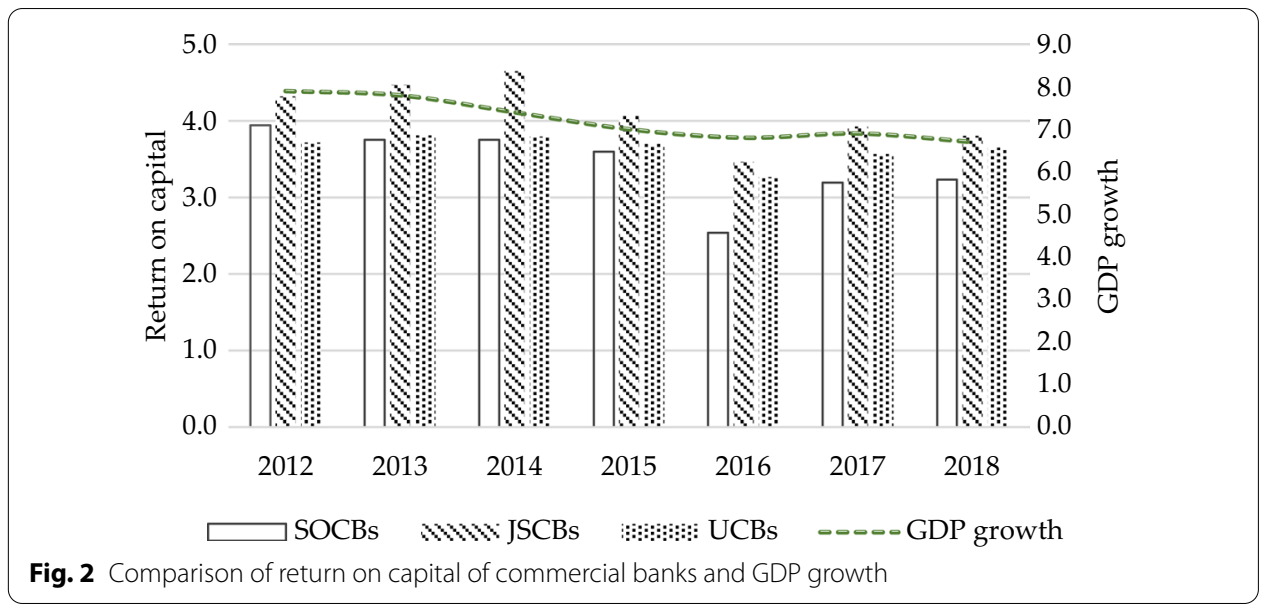

(2019) also pointed out that GDP has a significant impact on the profitability of real estate banks. When GDP is high and the national economy is developing well, the efficiency of banks is often also high. On the contrary, when GDP is low and macroeconomic environment is poor, banking efficiency is not ideal. Applying an innovative DEA method under a stochastic environment, the study of Chen et al. (2018) on banking efficiency in China was based on a sample of 127 banks at the height of the global financial crisis. Their empirical results showed that the overall efficiency level of Chinese banks is low.

Different economic development backgrounds lead to different businesses of banks, which affect the evaluation of bank performance. Therefore, taking GDP growth as an exogenous variable makes the model more logical and the measurement of banking efficiency more convincing. Figure 2 shows the relationship between GDP growth and return on capital from 2012 to 2018.

\section{Comparison of overall efficiency}

To ensure the rigor and scientific nature of the study, we also measure the performance of all DMUs without exogenous variables. We find that the efficiency value of commercial banks is generally low, and that the overall efficiency value of most commercial banks is lower than 0.5 , or even close to 0 . Here, the exogenous variables are not considered to have an interference effect in the study, which further supports the views of Lozano-Vivas et al. (2002) and Shyu et al. (2015). However, when GDP growth is taken into account, all three types of commercial banks perform well with an overall efficiency value of about 0.7 , and the differences among all kinds of banks are small. In general, SOCBs performed best, followed by JSCBs, while UCBs performed the worst. We note that the revised model combined with the GDP growth environmental variable can better evaluate the efficiency values of different commercial banks on the same comparison basis. See Table 5 for more details.

This paper takes GDP growth as an exogenous variable and considers the influence of a major economic environmental background on the efficiency of commercial banks, which is tenable and scientific. Based on this, GDP growth is used as an 
*

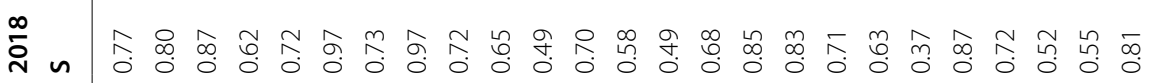

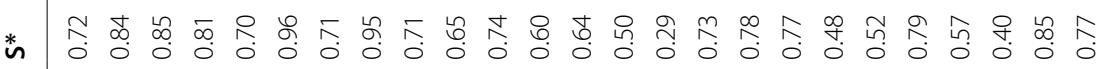

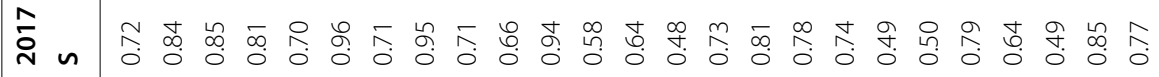

*

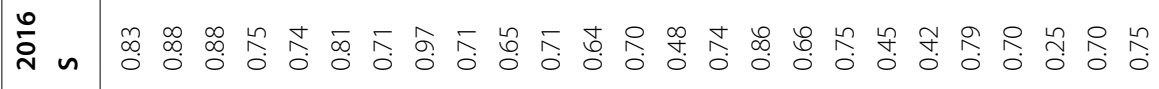

*

商 n

*

商 n

ش

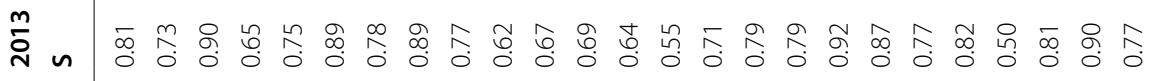

*

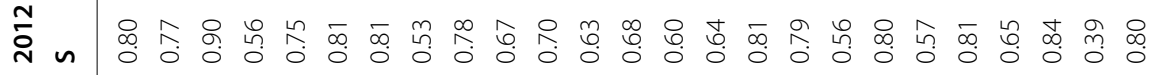

* 


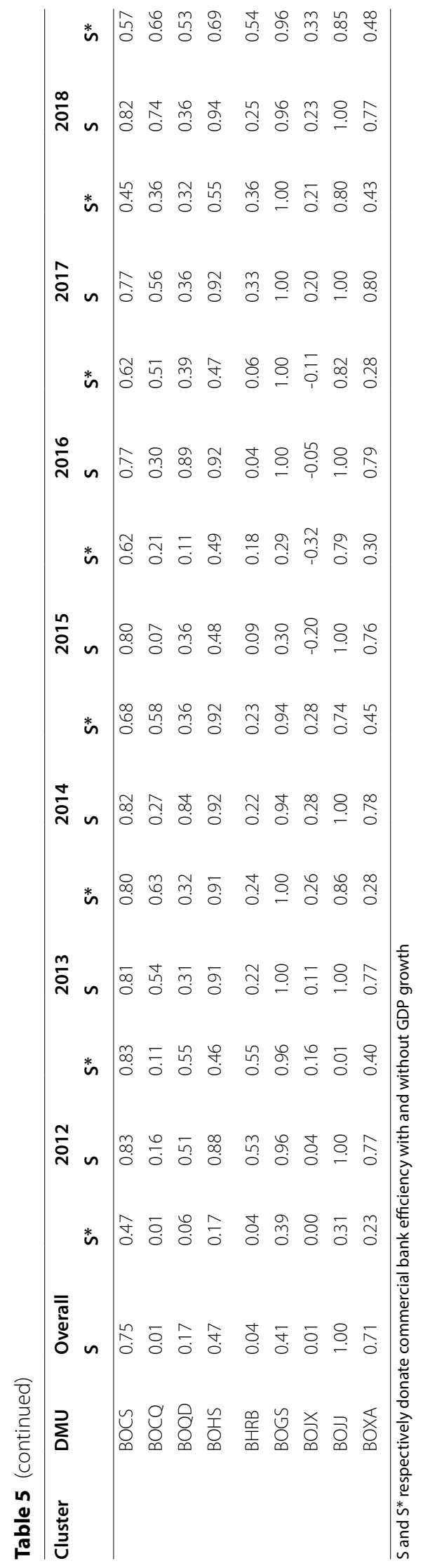




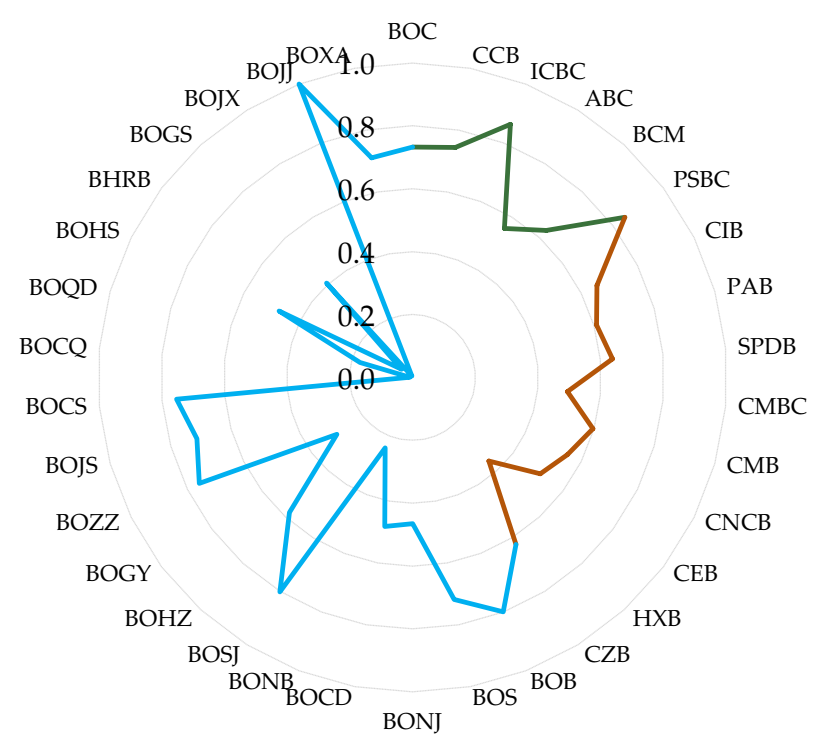

Fig. 3 Overall efficiency for each type of bank from 2012 to 2018 with an exogenous variable

Table 6 Overall Efficiency of Each Cluster from 2012 to 2018

\begin{tabular}{llllllll}
\hline Cluster & $\mathbf{2 0 1 2}$ & $\mathbf{2 0 1 3}$ & $\mathbf{2 0 1 4}$ & $\mathbf{2 0 1 5}$ & $\mathbf{2 0 1 6}$ & $\mathbf{2 0 1 7}$ & $\mathbf{2 0 1 8}$ \\
\hline SOCBS & 0.763 & 0.788 & 0.800 & 0.840 & 0.813 & 0.811 & 0.792 \\
JSCBs & 0.671 & 0.702 & 0.738 & 0.715 & 0.701 & 0.711 & 0.666 \\
UCBS & 0.668 & 0.716 & 0.723 & 0.562 & 0.630 & 0.674 & 0.680 \\
\hline
\end{tabular}

exogenous variable in the following analysis, and relevant discussions will be carried out accordingly.

To be more specific, SOCBs performed the best, while UCBs performed the worst. The average overall efficiency of the 6 SOCBs reached 0.8; the 19 UCBs, 0.66; and 9 JSCBs, 0.7. State-owned commercial banks are still the main force in China against the background of a good external financial development environment and the improvement of their own professional ability. For future development, the three types of commercial banks need to collectively improve their overall efficiency in all aspects.

Figure 3 shows the radar map of SOCBs (green), JSCBs (orange), and UCBs (blue) in overall efficiency with an exogenous variable. State-owned commercial banks performed the best at greater than 0.5 . The performance of JSCBs ranked second, but still has room to improve. The performance of UCBs is significantly lower than that of JSCBs, and most banks have a low efficiency value.

We now explore the overall efficiency of the three types of commercial banks from 2012 to 2018. In general, there is only a small increase or decrease between 0.7 and 0.8 in the overall efficiency of all kinds of commercial banks.

The overall efficiency of SOCBs reached the maximum value of 0.84 in 2015. The overall efficiency values in the remaining 6 years do not exceed 0.82 and fluctuate around 0.78 , showing the best performance. In general, the yearly change in the overall efficiency values of JSCBs is minimal. The overall efficiency of UCBs exceeds 0.7 for 2 consecutive 

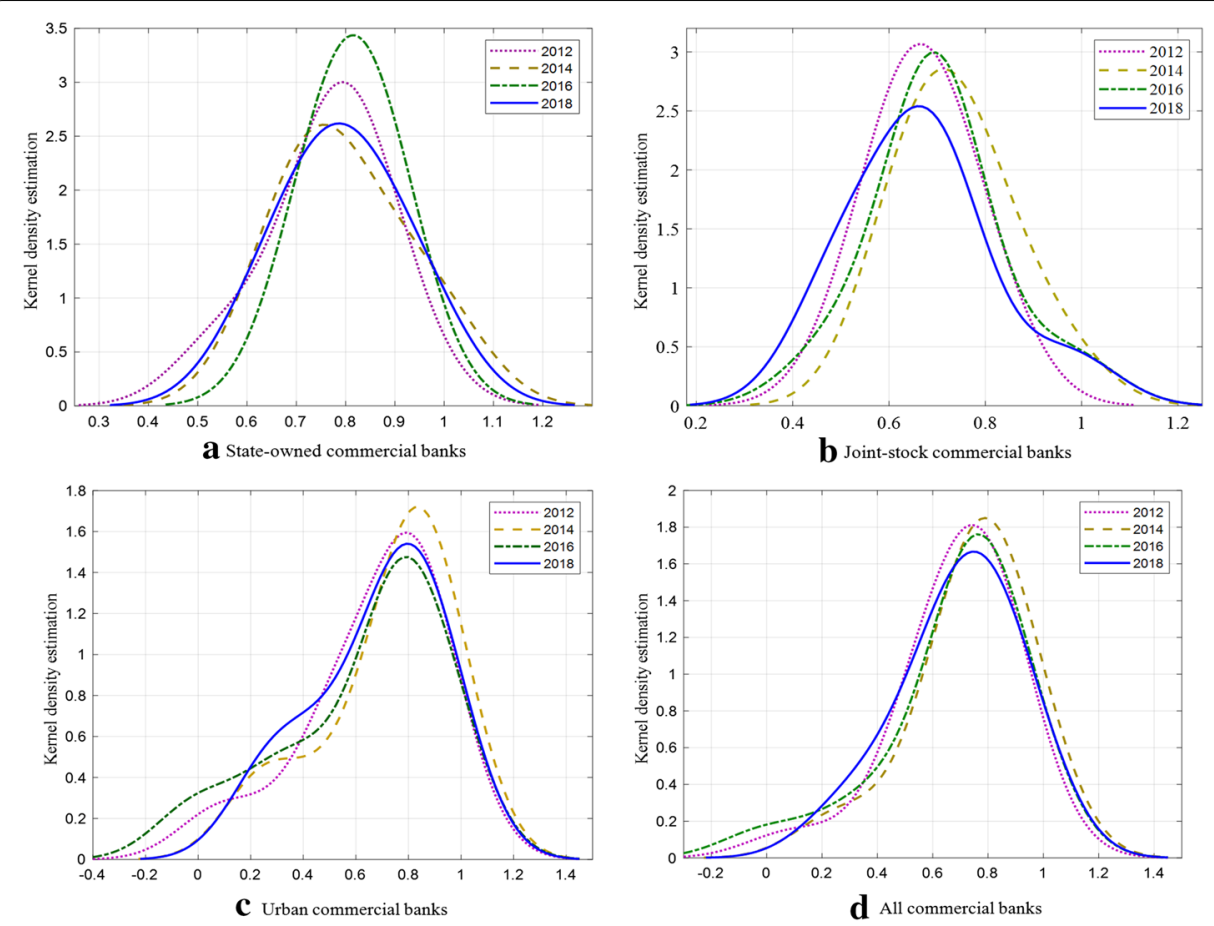

Fig. 4 Kernel density curve of overall efficiency for different commercial banks in 4 years. a state-owned; b joint-stock; c urban; $\mathbf{d}$ all

Table 7 Efficiency of the financing stage from 2012 to 2018

\begin{tabular}{llllllll}
\hline Cluster & $\mathbf{2 0 1 2}$ & $\mathbf{2 0 1 3}$ & $\mathbf{2 0 1 4}$ & $\mathbf{2 0 1 5}$ & $\mathbf{2 0 1 6}$ & $\mathbf{2 0 1 7}$ & $\mathbf{2 0 1 8}$ \\
\hline SOCBS & 0.845 & 0.864 & 0.912 & 0.977 & 0.956 & 1.000 & 0.946 \\
JSCBs & 0.748 & 0.836 & 0.904 & 0.911 & 0.922 & 0.898 & 0.849 \\
UCBS & 0.748 & 0.785 & 0.757 & 0.576 & 0.700 & 0.722 & 0.706 \\
\hline
\end{tabular}

years from 2013 to 2014 and reached the maximum value of 0.723 in 2014. The efficiency values of UCBs are presented below those of the other two types of banks. See Table 6 for further details.

From Table 6, we draw the Kernel density estimation curves of the overall efficiency of SOCBs, JSCBs, UCBs, and all commercial banks from 2012 to 2018 (Fig. 4).

In Fig. $4 \mathrm{a}$, the Kernel density estimation curve of the efficiency of SOCBs shows a "unimodal shape," with the peak fluctuation decreasing and moving slowly to the right. This shows an improvement in the efficiency of SOCBs, and that the overall difference between SOCBs is expanding. In Fig. 4b, the Kernel density estimation curve for the efficiency of JSCBs changes from a "unimodal shape," to a "wide peak shape" from 2012 to 2018, which shows that the differences between JSCBs are narrowing. In Fig. 4c, the Kernel density estimation curve initially moves to the left before moving to the right, and the efficiency of UCBs decreases before it gradually increases. The difference between each UCB is significant. In Fig. 4d, the Kernel density estimation curve gradually changes to a standard single peak type, and the differences among total commercial banks gradually 
Table 8 Efficiency of the investment stage from 2012 to 2018

\begin{tabular}{llllllll}
\hline Cluster & $\mathbf{2 0 1 2}$ & $\mathbf{2 0 1 3}$ & $\mathbf{2 0 1 4}$ & $\mathbf{2 0 1 5}$ & $\mathbf{2 0 1 6}$ & $\mathbf{2 0 1 7}$ & $\mathbf{2 0 1 8}$ \\
\hline SOCBS & 0.681 & 0.711 & 0.688 & 0.703 & 0.671 & 0.623 & 0.638 \\
JSCBs & 0.593 & 0.568 & 0.571 & 0.519 & 0.480 & 0.523 & 0.484 \\
UCBS & 0.589 & 0.646 & 0.689 & 0.548 & 0.561 & 0.627 & 0.654 \\
\hline
\end{tabular}

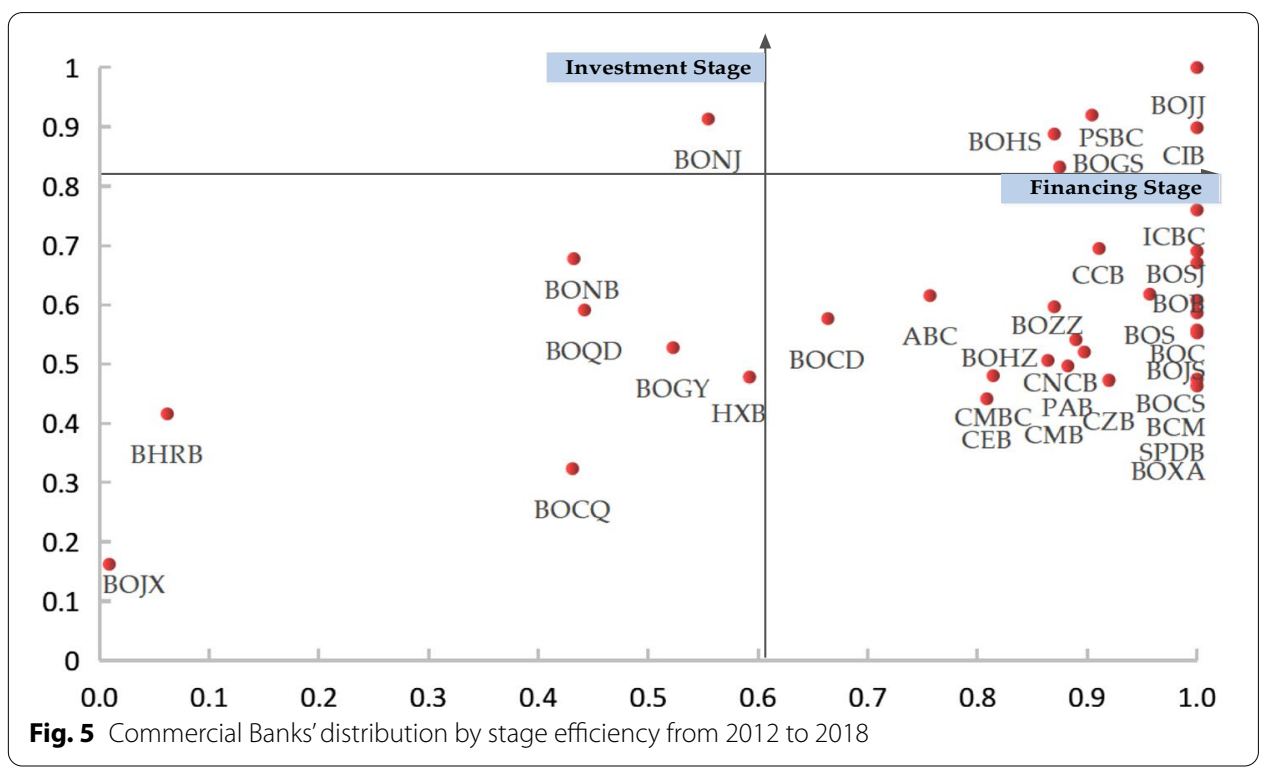

decrease. In general, the curve first moves to the left then to the right, indicating that the efficiency of all commercial banks falls, then rises.

\section{Efficiency comparison of financing stage and investment stage}

The efficiency of SOCBs, JSCBs, and UCBs in the financing stage is generally higher than that in the investment stage. The two-stage efficiency values of all kinds of banks are about 0.7 , requiring further improvement in the development level. Below, we analyze efficiency in detail from the perspectives of the financing stage and investment stage.

Financing is an important business of commercial banks; therefore, analyzing their efficiency in the financing stage is of great significance to their development. Stateowned commercial banks have the highest financing efficiency, followed by JSCBs, of which some have hit the optimal state during the research period. During the research period. the financing efficiency of JSCBs is generally on the rise. Urban commercial banks need to focus on efficiency at this stage. The efficiency at the financing stage is about 0.215 lower than that of SOCBs. See Table 7 for details.

The efficiency difference in the investment stage of the three commercial banks is small at about 0.55. Although the investment efficiency of JSCBs is relatively high, its efficiency value tends to slightly decline from 2012 to 2018. The efficiency of UCBs in the investment stage is slightly lower than that in the financing stage, while the efficiency of SOCBs in the investment stage is nearly 0.26 lower than that in the financing stage. We 


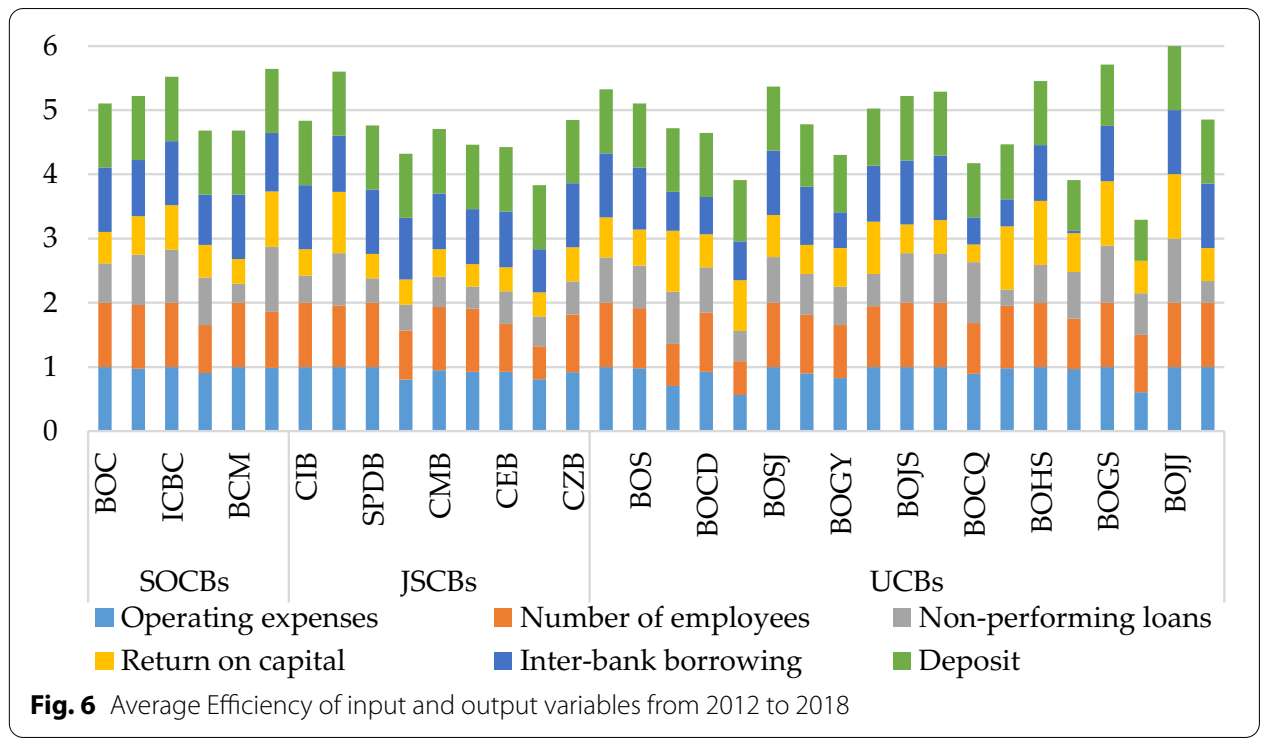

note that JSCBs need to focus on the flexible use of financing funds to improve investment efficiency on the basis of maintaining financing advantages. See Table 8 for details.

According to the calculation, the average efficiency value of the financing stage is 0.836 , and that of the investment stage is 0.608 . The development level of the financing stage is superior to the investment stage. See Fig. 5 for the two-stage efficiency distribution of 34 commercial banks.

\section{Improvement analysis}

In terms of the 7 years of improvement in input and output variables, non-performing loans and return on capital yielded the lowest values. Their values for the three types of commercial banks are around 0.6, lower than the values of other variables. Deposits yielded the highest value, and its profit value for the three banks is close to 1, approaching the optimal state.

Among the three types of commercial banks, SOCBs still have the best performance, followed by UCBs, then JSCBs. As far as SOCBs are concerned, the value of their return on capital on capital is about 0.589 . There is still room for funds management to be improved in SOCBs. The inter-bank borrowing value of UCBs is the lowest at 0.722 , which indicates that they still need to learn from the financing ability of the other two types of commercial banks despite rapid development. However, they have the highest return on capital value, indicating strong profitability. Overall, JSCBs performed poorly, and their input and output variables need further improvement. However, their deposit and inter-bank borrowing values are as high as 0.9 , which is near the optimal state and ranks second among the three types of banks. This shows that JSCBs have made great achievements in financing, which they need to maintain. See Fig. 6 for details. 


\section{Conclusions and suggestions}

Based on the UDSBM under an exogenous model, this paper analyzes the overall efficiency, stage efficiency, and variable improvement of SOCBs, JSCBs, UCBs in greater detail.

It is found that the performances of the three types of commercial banks in China are greatly affected by the macro-level environment, such as GDP growth. The existing literature (see, e.g., Tan et al. 2016; Liu et al. 2020) shows that SOCBs perform best. While this study confirms this view, it also finds that UCBs have recently been performing better despite lagging behind in earlier years. In addition, existing studies (see, e.g., An et al. 2019; Chen et al. 2020) suggested that banks need to strengthen their management of non-performing loans. This paper also finds that commercial banks need to pay attention to the investment stage. In the following section, we present conclusions and suggestions based on the above findings.

\section{Conclusions}

The overall efficiency of SOCBs is greater than that of JSCBs, while the overall efficiency value of UCBs is the lowest. With their strong growth base, SOCBs remain the leader of commercial banks. However, it is worth noting that the overall efficiency of UCBs fluctuates, and there is a gap of 0.036 from the average overall efficiency of JSCBs. This is because UCBs mainly serve local finance, enabling them to have a deeper understanding of their customers. Moreover, the government soundly supports their development. In addition, the overall scale of UCBs is small, and thus the mechanism is flexible and their independence is strong. The above positive factors help UCBs to become the best performing banks. The poor performance of JSCBs is a new finding of this study. Joint-stock commercial banks are 0.1 less efficient than SOCBs on average and performed worse than UCBs in 2013 and 2018. We speculate that this is because JSCBs have not effectively responded to the impact of macro-environmental factors such as GDP.

In terms of the two stages, the efficiency of the financing stage of SOCBs, JSCBs, and $\mathrm{UCBs}$ is better than that of the investment stage. Commercial banks have a strong ability to absorb funds, but a poor ability to operate them. In the financing stage, SOCBs is the most efficient, followed by JSCBs, while UCBs is the least efficient, which is predictable. However, in the investment stage, UCBs have the highest efficiency at 0.654, while JSCBs have the lowest efficiency at 0.484 , which is different from the previous development law. This may be because UCBs, as China's emerging banks, are geared toward local finance support. They are small in scale, flexible in mechanism, have strong financing capacity, and pay more attention to business development, therefore they can adapt to environmental risks and meet challenges. While the larger scale of assets or liabilities of SOCBs and JSCBs give them strong financing capability, it also leads to their inability to adjust their short-term corporate and asset structures. The profitability of JSCBs is weak in the context of GDP growth slowdown, market interest rate liberalization, and target customers for deleveraging enterprises.

All kinds of commercial banks have low non-performing loans and return on capital efficiencies. The average non-performing loan value of SOCBs, JSCBs, and UCBs is $0.711,0.48$, and 0.67 , respectively, and the value of return on capital is $0.589,0.466$, and 0.674 , respectively. 
The factors that contribute to this outcome include the following: First, the turbulence in the international financial market and unfavorable macroeconomic conditions in China. Second, the imperfect national regulatory system also leads to the emergence of non-performing loans to some extent. Third, some industries and enterprises in China have different degrees of operating difficulties, leading to blind credit or the inability to repay loans. Fourth, from the perspective of commercial banks themselves, weak risk awareness, imperfect credit management, and poor supervision mechanisms are also important factors. Therefore, all commercial banks must strive to reduce the amount of non-performing loans and improve profitability in all aspects in subsequent operation and management processes.

\section{Suggestions}

First, we recommend that SOCBs strengthen internal control, optimize risk management mechanism, and use big data to conduct comprehensive risk assessment and judgment on customers to reduce non-performing loans and improve return on capital. Second, while large banks prefer interbank financing, they should also focus on the expansion of the personal business sector. In recent years, individual customers have continuously demanded retail consumer goods and services, and consumption has become a part of the main force driving the economy. Therefore, SOCBs should enrich financial products and strengthen the development of their retail business. Third, banks should conduct reforms that are in line with the trend of the times and approach flat management at the organizational level. Fourth, SOCBs must consider the expansion of international business as senior banks in the context of global economic integration. Finally, governments at all levels should gradually reduce their influence on SOCBs and fully stimulate their vitality and creativity.

For JSCBs, we suggest that they follow the development trend of the Internet, diversify their financial services, and pay attention to their investment business. Second, when expanding their business, JSCBs must control costs, ensure operational safety, and adjust the structure of assets and liabilities to more timely adapt to the market. Third, they can establish a long-term talent incentive mechanism, strengthen enterprise culture, and accumulate talent advantages. Fourth, due to the integration of the global economy, JSCBs should follow modern steps and take the road to internationalization by opening branches in neighboring countries to expand their business.

As a new entity in the banking industry, UCBs can improve their banking governance structure, optimize operations and management, and strengthen their risk management mechanism. For example, upper management should perform their respective supervisorial duties, cultivate excellent credit risk management personnel, and reduce the amount of non-performing loans. Second, the asset scale of UCBs cannot meet the capital needs of large customers because it is not as large as the other two types of commercial banks. Therefore, UCBs should aim for correct market positioning rooted in local characteristics, maintain good relationships with local customer service, take the road of differentiated financial development, and seize opportunities for development. Third, on the basis of paying attention to traditional loan services, UCBs should promote the diversification of service products, comprehensively expand their business, and develop the matching equity scale to improve profitability. Fourth, all city governments should reach relevant agreements to provide preferential policies or support the crosscity operations of UCBs. 


\section{Acknowledgements}

Not applicable.

\section{Authors' contributions}

Z.S. carried out the data curation, participated in the methodology and drafted the manuscript. S.Q. carried out the visualization and drafted the manuscript. Y.-h.C participated in project administration. X.T. participated in the design of the study and performed the statistical analysis. X.M. participated in writing-review and editing. All authors have read and agreed to the published version of the manuscript.

\section{Funding}

Not applicable.

\section{Availability of data and materials}

The data used in this research paper are public, obtained from the Bankscope Database and from the National Bureau of Statistics site (http://www.stats.gov.cn/).

\section{Declarations}

\section{Competing interests}

The authors declare no conflict of interest.

\section{Author details}

${ }^{1}$ Business School, Hohai University, Changzhou, China. ${ }^{2}$ Department of Economics, Soochow University, Taipei City, Taiwan.

Received: 21 October 2020 Accepted: 30 April 2021

Published online: 12 May 2021

\section{References}

Afza T, Asghar MJEKA (2017) Efficiency of Commercial Banks in Pakistan: application of SFA and value added approach. Argumenta Oeconomica 38(1): 195-220. https://doi.org/https://doi.org/10.15611/aoe.2017.1.07

Allen J, Engert W, Liu Y (2006) Are Canadian Banks Efficient? A Canada--U.S. Comparison. Staff Working Papers 63.

An Q, Liu X, LiY, Xiong B (2019) Resource planning of Chinese commercial banking systems using two-stage inverse data envelopment analysis with undesirable outputs. Plos One 14(6). https://doi.org/https://doi.org/10.1371/journal.pone.0218214

Ausloos M, Ma Q, Kaur P, Syed B, Dhesi G (2019) Duration gap analysis revisited method in order to improve risk management: the case of Chinese commercial bank interest rate risks after interest rate liberalization. Soft Comput 24(18):13609-13627. https://doi.org/10.1007/s00500-019-04376-7

Banker RD, Charnes A, Cooper WW (1984) Some models for estimating technical and scale inefficiencies in data envelopment analysis. Manage Sci 30(9):1078-1092. https://doi.org/10.1287/mnsc.30.9.1078

Calmes C, Theoret R (2020) Bank fee-based shocks and the U.S. business cycle. N Am J Econ Finance 51. https://doi. org/https://doi.org/10.1016/j.najef.2018.09.002

Calmès C, Théoret R (2020) Portfolio analysis of big US Banks' performance: the fee business lines factor. J Bank Regul. https://doi.org/10.1057/s41261-020-00131-3

Chao X, Kou G, Peng Y, Viedma EH (2021) Large-Scale group decision-making with non-cooperative behaviors and heterogeneous preferences: an application in financial inclusion. Eur J Oper Res 288(1):271-293. https://doi.org/10. 1016/j.ejor.2020.05.047

Charnes A, Cooper WW, Rhodes E (1978) Measuring the efficiency of decision making units. Eur J Oper Res 2(6):429-444. https://doi.org/10.1016/0377-2217(78)90138-8

Chen S, Hardle WK, Wang L (2020) Estimation and determinants of Chinese banks'total factor efficiency: a new vision based on unbalanced development of Chinese banks and their overall risk. Comput Stat 35(2):427-468. https://doi. org/10.1007/s00180-019-00951-6

Chen Z, Li K, He LY (2019) Has internet finance decreased the profitability of commercial banks? Evidence from China. Emerg Mark Financ Trade 56(13):3015-3032. https://doi.org/10.1080/1540496X.2019.1624159

Chen Z, Li Y, Wu Y, Luo J (2017) The transition from traditional banking to mobile internet finance: an organizational innovation perspective: a comparative study of Citibank and ICBC. Financial Innovation 3(1):1-16. https://doi.org/10. 1186/s40854-017-0062-0

Chen Z, Matousek R, Wanke P (2018) Chinese bank efficiency during the global financial crisis: a combined approach using satisficing DEA and support vector machines. N Am J Econ Finance 43:71-86. https://doi.org/10.1016/..najef.2017.10.003

Fang J, Lau CKM, Lu Z, Tan Y, Zhang H (2019) Bank performance in China: a perspective from bank efficiency, risk-taking and market competition. Pac Basin Financ J 56:290-309. https://doi.org/10.1016/j.pacfin.2019.06.011

Farrell MJ (1957) The measurement of productive efficiency. J R Stat Soc 120:253-290. https://doi.org/10.2307/2343100

Guo L, Na S, Tan X, Gui P, Liu C (2020) Evolution of the efficiency of nationwide commercial banks in China based on an SBM-undesirable model and DEA window analysis. Math Probl Eng. https://doi.org/10.1155/2020/4682790

Ji G, Kim DS, Ahn K (2019) Financial structure and systemic risk of banks: evidence from Chinese reform. Sustainability 11(13). https://doi.org/https://doi.org/10.3390/su11133721

Karkowska R, Acedanski J (2020) The effect of corporate board attributes on bank stability. Port Econ J 19(2):99-137. https://doi.org/10.1007/s10258-019-00162-3

Kou G, Chao X, Peng Y, Alsaadi FE, Herrera-Viedma E (2019) Machine learning methods for systemic risk analysis in financial sectors. Technol Econ Dev Econ 25(5):716-742. https://doi.org/10.3846/tede.2019.8740

Kou G, Peng Y, Wang G (2014) Evaluation of clustering algorithms for financial risk analysis using MCDM methods. Inf Sci 275:1-12. https://doi.org/10.1016/j.ins.2014.02.137 
Kou G, Xu Y, Peng Y, Shen F, Chen Y, Chang K, Kou S (2021) Bankruptcy prediction for SMEs using transactional data and two-stage multiobjective feature selection. Decis Support Syst. https://doi.org/10.1016/j.dss.2020.113429

Kweh QL, Lu WM, Nourani M, Zaind MHGM (2018) Risk management and dynamic network performance: an illustration using a dual banking system. Appl Econ 50(30):3285-3299. https://doi.org/10.1080/00036846.2017.1420889

Liu X, Sun J, Yang F, Wu J (2020) How ownership structure affects bank deposits and loan efficiencies: an empirical analysis of Chinese commercial banks. Ann Oper Res 290(1-2):983-1008. https://doi.org/10.1007/s10479-018-3106-6

Lozano-Vivas A, Pastor JT, Pastor JM (2002) An efficiency comparison of European banking system operating under different environmental conditions. J Prod Anal 18(1):59-77. https://doi.org/10.1023/A:1015704510270

Martins AM, Serra AP, Stevenson S (2019) Determinants of real estate bank profitability. Res Int Bus Financ 49:282-300. https://doi.org/10.1016/j.ribaf.2019.04.004

Mester LJ (1997) Measuring efficiency at US Banks: accounting for heterogeneity is important. Eur J Oper Res 98(2): 230-242.10. https://doi.org/https://doi.org/10.1016/S0377-2217(96)00344-X

O'Donnell CJ, Rao DSP, Battese GE (2008) Metafrontier frameworks for the study of firm-level efficiencies and technology ratios. Empir Econ 34(2):231-255. https://doi.org/10.1007/s00181-007-0119-4

Phan HT, Anwar S, Alexander WRJ, Phan HTM (2019) Competition, efficiency and stability: an empirical study of East Asian commercial banks. N Am J Econ Finance. https://doi.org/10.1016/j.najef.2019.100990

Rehman RU, Zhang J, Naseem MA, Ahmed Ml, Ali R (2020) Board independence and Chinese banking efficiency: a moderating role of ownership restructuring. Eurasian Bus Rev. https://doi.org/10.1007/s40821-020-00155-9

Shen L, Cai Z (2020) Improved multi-objective neural network to the complex investment decision-making evaluation. Int J Electr Eng Educ. https://doi.org/10.1177/0020720920923306

Shi Z, Huang H, Wu Y, Chiu YH, Qin S (2020) Climate change impacts on agricultural production and crop disaster area in China. Environ Res Public Health 17(13). https://doi.org/https://doi.org/10.3390/ijerph17134792

Shyu J, Lieu PT, Chang W (2015) How the environment determines banking efficiency: a comparison of banking firms in Taiwan, Hong Kong, and Mainland China. Int Trans Oper Res 22(4):757-770. https://doi.org/10.1111/itor.12097

Sun J, Wang C, Ji X, Wu J (2017) Performance evaluation of heterogeneous bank supply chain systems from the perspective of measurement and decomposition. Comput Ind Eng 113: 891-903. https://doi.org/https://doi.org/10.1016/j.cie.2017.05.028

Tan Y (2016) The impacts of risk and competition on bank profitability in China. J Int Financ Mark Inst Money 40:85-110. https://doi.org/10.1016/j.intfin.2015.09.003

Tang G, Chiclana F, Lin X, Liu P (2020) Interval type-2 fuzzy multi-attribute decision-making approaches for evaluating the service quality of Chinese commercial banks." Knowl-Based Syst 193. https://doi.org/https://doi.org/10.1016/j. knosys.2019.105438

Tang SH, Nguyen LT (2020) Financial development, business cycle and bank risk in southeast Asian countries. J Asian Finance Econ Bus 7(3): 127-135. https://doi.org/https://doi.org/10.13106/jafeb.2020.vol7.no3.127

Tone K (2001) A slacks-based measure of efficiency in data envelopment analysis. Eur J Oper Res 2(130):498-509. https:// doi.org/10.1016/S0377-2217(99)00407-5

Tone K, Tsutsui M (2009) Network DEA: a slacks-based measure approach. Eur J Oper Res 197(1):243-252. https://doi.org/ 10.1016/j.ejor.2008.05.027

Tone K, Tsutsui M (2010) Dynamic DEA: a slacks-based measure approach. Omega 38:145-156. https://doi.org/10.1016/j. omega.2009.07.003

Unvan YA, Yakubu IN (2020) Do bank-specific factors drive bank deposits in Ghana? J Comput Appl Math. https://doi.org/ 10.1016/j.cam.2020.112827

Wang H, Kou G, Peng Y (2020) Multi-class misclassification cost matrix for credit ratings in Peer-to-Peer lending. J Oper Res Soc. https://doi.org/10.1080/01605682.2019.1705193

Xu G, Zhou Z (2020) Assessing the efficiency of financial supply chain for Chinese commercial banks: a two-stage AR-DEA model. Ind Manag Data Syst. https://doi.org/10.1108/IMDS-01-2020-0022

Xu Z, Cheng X, Wang K, Yang S (2020) Analysis of the environmental trend of network finance and its influence on traditional commercial banks. J Comput Appl Math 379. https://doi.org/https://doi.org/10.1016/j.cam.2020.112907

Xue J, Zhu D, Zhao L, Wang C, Li H (2019) Redundancy identification and optimization scheme of branches for sustainable operation of commercial Banks. Sustainability 11 (15). https://doi.org/https://doi.org/10.3390/su11154111

Zhang L, Hsu S, Xu Z, Cheng E (2020a) Responding to financial crisis: bank credit expansion with Chinese characteristics. China Econ Rev. https://doi.org/10.1016/j.chieco.2018.09.014

Zhang X, Li F, Li Z, Xu Y (2018) Macroprudential policy, credit cycle, and bank risk-taking. Sustainability 10(10). https://doi. org/https://doi.org/10.3390/su10103620

Zhang A, Wang S, Liu B, Fu J (2020) How government regulation of interbank financing impacts risk for Chinese commercial banks. J Asian Econ 66. https://doi.org/https://doi.org/10.1016/j.asieco.2019.101148

Zhao B, Kenjegalieva K, Wood J, Glass A (2020) A spatial production analysis of Chinese regional banks: case of urban commercial banks. Int Trans Oper Res 27(4):2021-2044. https://doi.org/10.1111/itor.12732

Zhu F, Chen J, Chen Z, Li H (2019) Shadow banking shadowed in banks' balance sheets: evidence from China's commercial banks. Acc Finance 59(5):2879-2903. https://doi.org/10.1111/acfi.12558

Zhu N, Hougaard JL, Yu Z, Wang B (2020a) Ranking Chinese commercial banks based on their expected impact on structural efficiency. Omega-Int J Manag Sci. https://doi.org/10.1016/j.omega.2019.03.007

Zhu C, Hua G (2020) The impact of China's Internet Finance on the banking systemic risk-an empirical study based on the SCCA model and stepwise regression. Appl Econ Lett 27(4):267-274. https://doi.org/10.1080/13504851.2019.1613494

Zhu Q, Li X, Li F, Amirteimoori A (2020b) Data-driven approach to find the best partner for merger and acquisitions in banking industry. Ind Manag Data Syst. https://doi.org/10.1108/IMDS-12-2019-0640

\section{Publisher's Note}

Springer Nature remains neutral with regard to jurisdictional claims in published maps and institutional affiliations. 